\title{
Language Practitioners' Reflections on Method-based and Post-method Pedagogies
}

\author{
Abdul Fattah Soomro ${ }^{1} \&$ Mansoor S. Almalki ${ }^{2}$ \\ ${ }^{1}$ English Language Centre, Deanship of Supportive Studies, Taif University, Saudi Arabia \\ ${ }^{2}$ English Language Centre, Deanship of Supportive Studies, Taif University, Saudi Arabia \\ Correspondence: Abdul Fattah Soomro, English Language Centre, Deanship of Supportive Studies, Taif \\ University, PO Box 888, Taif 21974, Kingdom of Saudi Arabia
}

\author{
Received: March 25, 2017 Accepted: April 25, 2017 Online Published: April 27, 2017 \\ doi: 10.5539/elt.v10n5p234 URL: http://doi.org/10.5539/elt.v10n5p234
}

\begin{abstract}
Method-based pedagogies are commonly applied in teaching English as a foreign language all over the world. However, in the last quarter of the $20^{\text {th }}$ century, the concept of such pedagogies based on the application of a single best method in EFL started to be viewed with concerns by some scholars. In response to the growing concern against the concept of a method, some scholars started to offer alternatives to a method in different forms. Kumaravadivelu is one of the scholars who offers his post-method macro-strategic framework as an alternative to method-based pedagogies. This small-scale study explores English language practitioners' experience and their views about applying method-based and post-method pedagogies. Semi-structured pre- and post-interviews were conducted from eight participants. The pre-interviews investigated the teacher-participants' views about the method-based pedagogies in practice and the post-interviews aimed at knowing the prospects and concerns in the application of post-method pedagogies in their context. Although participants were skeptical of the concept of methods, they considered them useful in making contribution towards learning and teaching English. They found post-method pedagogies as more preferable option to method-based pedagogies in ELT on the ground; the post-method pedagogies, according to them, give broad directions while specific methods make teachers to work within narrow guidelines. However, they showed certain concerns in the application of such pedagogies in their context.
\end{abstract}

Keywords: post-method pedagogies, method-based pedagogies, macro-strategic framework

\section{Introduction}

Approaches towards learning and teaching a foreign language especially English keep changing with the emergence of new knowledge in the field of language learning and teaching. The change in approach towards English Language Teaching (ELT) is described by a variety of terms and labels (see for instance Antony, 1963, Richards and Rodgers 1982, Kumravadivelu, 2006). Among these labels, the method is the most central term, used quite often in the field of ELT profession. Mushrooming of methods and their importance at the expense of teaching made many scholars in the field of L2 teaching sceptical not only of the importance but also of the concept of methods in L2 teaching. The scholars found that methods are limited in their approaches to explain and accommodate unpredictably numerous learning needs and teaching situations that teachers confront in their everyday professional lives. The limited nature of the methods has been realized that 'the term method is a label without substance' (Clarke, 1983: 109 cited in Kumaravadivelu, 2003), and a method has 'diminished rather than enhanced our understanding of language teaching' (Pennycook, 1989: 597) and that 'language teaching might be better understood and better executed if the concept of method were not to exist at all' (Jarvis, 1991: 295). Gregg (1986) thinks that language acquisition theories are unhelpful and anti-teacher, especially methods of language teaching, which need to be addressed on immediate basis (cited in Pennycook, 1989). Stern (1983) is of the view that there is a 'fundamental weakness' in the concept of method and believes that it is not possible to achieve the desired goal of language teaching through use of language methods alone.

\subsection{Research Objectives}

The research focuses on evaluating the effectiveness of method-based and post-method pedagogies in practice by English language practitioners so that we could contribute to the debate about the significance and 
appropriateness of alternative pedagogies in EFL. The current study also aims to know the prospects of post method pedagogies with special reference to Kumaravadivelu's macr strategic framework. The main objectives of the research are:

- Evaluating the effectiveness of method-based pedagogies

- Evaluating the effectiveness of post-method pedagogies.

- Determining the prospects and concerns of applying method-based pedagogies

- Determining the prospects and concerns of adopting post-method pedagogies

\subsection{Significance of the Study}

In response to a growing concern against the concept of method and its limitations, there have evolved some frameworks that are said to be post-method in their orientation. Post-method in a way that these frameworks do not adhere to a specific set of classroom procedures with a specific set of theoretical principles as is in the case of a traditional method. And these frameworks are said to provide broad guidelines instead of narrow techniques and are informed not only by a single theory, but also by a set of theories evolved over a period of time in L2 field. These frameworks make a clear break with the concept of method and offer a well-defined set of ideas that can govern important aspects of L2 classroom activity. The popular frameworks that are identified as post-method in their approach towards learning language is Stern's three-dimensional framework (1992), Allwrigth's exploratory framework (1991) and Kumaravadivelu's post-method framework (1994). The macro strategic framework of Kumaravadivelu (1994) is founded on three pedagogic parameters: a pedagogy of particularity, practicality, and possibility. He believes that his macro strategic framework, which consists of ten macro strategies, provides prospective teachers with broader guidelines to develop their own 'situation-specific' and 'need-based classroom techniques' or micro strategies. The suggested macro strategies and situated micro strategies can be very supportive for teachers to start building 'their own theory of practice' (Kumaravadivelu, 2003: 38).

The supporters of post-method framework claim that "teachers find themselves in an unenviable position where they have to straddle two pedagogic worlds: a method-based that is imposed on them, and a methodological that is improvised by them" (Kumaravadivelu, 2008: 170). However, Akbari (2008) argues that although the advocates of post-method pedagogies think they help teachers develop their own strategies, suitable to their learners, in their respective learning contexts; critics of this framework maintain that this is an idealistic approach which is very difficult for the practitioners to practice in reality. He (ibid) thinks that teachers confront a variety of constraints as a part of their responsibilities in their professional lives, such as over-crowded classes, extra work-load, the demands/requirements of the institutes which do not allow them to work autonomously, constraints of covering specific textbooks with suggested methodology and conducting prescribed tests and quizzes. In such working environment, teachers may avoid subscribing to a method which is imposed on them.

\section{Literature Review}

Huda (2013), while dwelling on the effectiveness of Kumaravadivelu post-method framework in the EFL context of Bangladesh, posits that to a large extent the concept of the post-method pedagogy is both useful and applicable. However, he supposes that certain aspects of this framework are neither practicable nor appropriate for the context. English teachers, according to him, are over expected by being asked "to theorize from their practice and practice what they theorize". Teachers are not equally qualified and competent enough to do this. Post-method framework expects practitioners to "understand and identify problems, analyze and assess information, consider and evaluate alternatives, and then choose the best available alternative that is then subjected to further critical evaluation" (Kumaravadivelu, 2006: 173). According to Huda (2013), this is very difficult for teachers to practice due to number of contextual, academic and personal limitations. He is also critical of the concept of learner autonomy as suggested by Kumaravadivelu post-method framework. According to him, the concept of learners' autonomy do not co-exist with the cultural profiles and background of the learners. He (ibid), citing on Shahidullah (1997), reports that learners in Bangladesh learn better under the controlled guidance of the teachers. Huda (2013), dwelling on the concept of teachers' empowerment and autonomy, agrees with Akbari (2008) that the post-method framework does not take into account the social and professional constraints English professionals face while working in different contexts. Teachers don't enjoy much freedom in making their own decision and performing as they will.

Motlhaka (2015), exploring the prospects of post-method pedagogy in the EFL context of South Africa, reports that post-method frameworks help lecturers understand the limitations of method-based pedagogies and recognize their potential to develop context sensitive strategies useful for their professional development. He 
suggests that teachers may utilize their experiences and knowledge in the light of broad guidelines of post-method framework to move from the role of being mere consumers of knowledge to that of producers of it. In addition, the post-method pedagogy incorporates learning needs of students and helps teachers develop suitable classroom activities matching the learning styles. He thinks that post-method framework, if applied in the EFL context, would help students get them engaged in meaningful classroom interactions to develop real communication beyond the walls of the classrooms.

The mentioned studies conducted on evaluating the significance of post-method pedagogies are based on the theoretical analysis, the present study investigates the views and perception of teachers about method-based and post-method pedagogies. Teachers can provide better understanding about the significance of different pedagogies employed by them. In this regard, Johnson (2006) maintains that better understanding of the works of L2 teachers could be developed by the research on teacher cognition. This research explores mental lives of teachers (Walberg, 1977; Freeman, 2002) about different pedagogies in the light of their past experiences, how they understand and explain the activities they remain engaged in, and the contexts where they teach. The current study also seeks to contribute towards a literary debate about the use of method-based and post-method pedagogies in the field of L2 teaching by answering the following questions:

- How do language practitioners evaluate the effectiveness of method-based pedagogies?

- What are the prospects and concerns of applying post-method pedagogies?

\section{Methodology}

Semi-structured interviews were conducted from eight participants. First, interviews were conducted to know what approaches/methods were being used by the participants in their practice as language teachers. Interviews with the participants helped the researchers investigate about their concerns and difficulties, prospects and advantages with the use of their current approaches. Detailed discussion was also made during the interview about the nature of such difficulties (as faced by them and possible solutions as suggested by them). The second interview (post-narrative interview) was conducted after almost two days of their first interview. During the gap between pre-interview and post-interview, participants were requested for reading two seminal works of Kumaravadivelu on post-method framework (Post-method condition:(E)merging strategies for foreign language teaching published in 1994 and Towards a post-method pedagogy published in 2001). The participants were already familiar with the concept of post-method framework. The reason the researchers made reading of such articles compulsory for the participants was that to refresh their memory of this framework or in case they did not know about the post-method, they would try to grasp the idea of it. During that gap, the researchers remained in touch with the participants to know if there had been any difficulties in understanding the idea of post-method. The second interview was conducted after making sure that each participant had read these articles. The second interview investigated the views of participants about the concept of post-method condition and post-method pedagogy with special reference to the use of post-method framework in their teaching and learning context.

\subsection{The Participants and Procedure}

In the beginning, the potential participants of the study were first contacted and then the protocol-letters describing the nature of the study and time required for the participation were sent to them. All of these participants are English language teachers working at a tertiary level. As Goetz and LeCompte (1984) point out that the key informant tends to be reflective individuals who can speak well about the specific issue. Thus, eight English teachers were recruited to participate in the study. All of them had more than 10 years of teaching experience and had better knowledge of the topic under inquiry.

\subsection{Data Analysis}

Analysis of semi-structured interviews was done through thematic analysis. Thematic analysis is a process of identifying, describing, analysing, and reporting themes and patterns drawn from data (Braun \& Clarke, 2006). It employs two different ways of identifying themes: inductive approach and theoretical deductive approach (Braun \& Clarke, 2006). The former approach is termed as an arbitrary and overt. The latter approach, though does not provide a detailed description of the data, focuses on a more detailed analysis of certain aspects of the data required to answer the research questions (ibid.). Usually, thematic approach develops report by interpreting themes in connection with the relevant literature (ibid.). The current study employs a deductive approach (Tyson, 2011) in which pre-set codes were borrowed from the literature in accordance with the requirements of the research questions.

\section{Analysis of Findings}

The results of interview data, collected through pre- and post-interviews with the participants are being 
presented.

\subsection{The Concept of method in ELT}

The participants employed different methods in their teaching. One of the teacher-participants told that he started his teaching career by taking his teachers as the role models. Although he does not use any specific method in his practice as a language practitioner, he finds his teaching quite close to Grammar Translation Method (GTM). Another participant considers Communicative Language Teaching (CLT) as the best method but she believes it has not helped her to achieve the desired results in terms of learning outcomes especially in developing communicative competency among her participants (students). According to one teacher-participant, the concept of method is useful in ELT in terms of its contribution towards learning and teaching English. He treats methods as theories of learning based on linguistic knowledge and suggests that language practitioners need to learn from these theories/methods.

Some participants were of the view, since knowledge is open to all in this era of communication and internet, books and journals, they do not rely on a single method or a single theory of learning. So they shared the same concerns by saying that language practitioners come across numerous situations varying from one extreme to another such as difference in students' language background, their interests and attitude towards learning the target language, preoccupation with preparation for the exams, difference in the talent among them, the level of confidence etc. Among these various situations, as they believe, language practitioners will have to adopt a moderate stand that can maximize the potential benefits as teachers need to be updated with previous and recent knowledge related to the field of L2 teaching. Teachers, then, can apply more than one method depending upon the level of students in a class, for example one of the participants said, "he uses a different method for the the second year students and uses a different method with students in the first year of their studies at university level. He does this because he finds no benefit of using Communicative Language Teaching (CLT) with those students who are unable to utter a single sentence in the target language (English), so in such circumstances, he finds GTM quite useful". Another teacher-participant believes, "it is not possible to carry out activity of teaching without any method". He, further, says "teaching is like an abstract idea and method is its materialization or actualization of it". In this regard, one more participant remarked, "the methods were probably useful at different periods/ages - one method was useful at one time and another method was useful at some other times". Overall, all the participants were sceptical of the concept of methods in ELT because they foresee a lot of contextual hindrances in the application of a specific method in their context.

\subsection{Views about Importing Method}

Teacher-participants were not sure that any teacher may be able to practice any specific method in its pure form even after being trained in the same method. The actualization of method in its pure form, according to them, depends upon the contextual realties of a specific context. They, therefore, advocate the idea of importing methods on the condition of testing them to see if they work well in any specific context. They, in general, criticised the concept of importing a single method from abroad and applying it in any context including their own. They believe it is not possible to practice a specific method such as CLT or Suggestopedia in pure forms due to the contextual variations These contextual factors include number of things. There is less encouragement and support from the officials. Curriculum is not designed to confirm to that type of teaching. There is dearth of resources. Mentioning the reason of why he applies GTM then, one of the participants remarked, "GTM confirms better than any other method to our contextual realities and meets the purpose of preparing students for the exams". Majority of the participants did not think it would become useful to import a single method from abroad and impose it on language practitioners in their context. Because, they believe, action of importing method will impede the process of language teaching instead of progressing it due to various factor such as providing competent faculty with full training in a specified method; adjusting syllabus to the need of a new method; and considering socio-cultural backgrounds of the students.

\subsection{Suggestion about Improving ELT Conditions}

Teacher-participants proposed different suggestions for improving the ELT conditions in their context. They suggested the idea of exploring methods within their specific context. In this regard, one of the participants said, "he has probably explored some methods that he calls 'a new way of expression' or 'natural methods'. They also suggested that methods of teaching could be imported on the condition of testing them to see if these methods would work well in their context. They appreciated the concept of eclecticism instead of applying a single method because they think that eclecticism is a concept in ELT which recommends the use of various aspects from different methods instead of employing a single method. According to them, for improving ELT conditions in their respective context, it is necessary to empower teachers with necessary skills and knowledge to develop 
methods appropriate to their own situations. They reiterated the point that a method could only be successful when teachers are involved in developing it. They also mentioned that the authorities concerned must focus on the education of teachers instead of just importing methods to improve ELT conditions in the context. They maintained that if they could educate their teachers properly through training (professional development opportunities), providing resources (access to books and journals), encouraging them with promotional and monetary rewards and inspiring them to become-teacher researcher, they think it would not take too long to improve ELT conditions in their context.

\subsection{The comparison between Method-based and Post Method Pedagogies}

The participants found post-method pedagogies as a more preferable option to method-based pedagogies in ELT on the ground; the post-method pedagogies, according to them, give broad directions while specific methods make teachers to work within narrow guidelines. Thus, according to them, post-method pedagogies are accommodative to the socio-cultural background of the participants in any teaching and learning context. However, one of the participants remarked, "it is not possible at the moment to declare any verdict about what is better among method-based or post-method pedagogy. It needs a lot of work and efforts to evaluate the significance of the post method pedagogy before adopting it". Comparing post-method with method-based pedagogies, one of the participants appreciated the post-method pedagogies by saying post-method pedagogies provide broad guidelines and can easily be fit into any teaching and learning context including his own while the method-based pedagogies are narrow approaches that sometimes do not adjust in some contexts and create hindrances for both teachers and students. One participant considered the post method framework of Kumaravadivelu as "insightful, interesting, and context-based with sociocultural touches". Another research-participant, while appreciating the idea of post-method pedagogies remarked that she has learnt in her experience of teaching for many years that it's not possible for a teacher to follow a specific method as he/she faces numerous unpredictable situations so the better alternative is to adopt post-method pedagogies. In contrast to the views of the majority of the participants, two participants believe that the emergence of post-method in L2 teaching is by virtue of the existence of method-based pedagogies so they think that it would be unjust to say method-based pedagogies are useless and quite unhelpful for teachers.

\subsection{The idea about Post-method Condition and Post Method Pedagogy}

Majority of the participants agree with the idea of Kumaravadivelu to search for an alternative to methods on the basis of 'theorizing from the practice and practicing what has theorized'. In this regard, one participant remarks that he has been doing the practice of theorizing one's own practice and practicing the theory on daily basis. But, he says if we (all teachers) do this practice formally by maintaining diary and arranging discussions, we can get a lot more positive result from this practice. One of the participants disagrees with Kumaravadivelu's idea of searching for an alternative to method on the basis of 'theorising from the practice and practicing from what has theorized'. Because, she believes, this practice can help a teacher for his professional development but not pave the way for developing 'an alternative to method'. She says she might have been doing this practice of theorising from one's own practice unconsciously because it is a very essential characteristic of being a good teacher. Probably, by virtue of this technique there is meditation on her own teaching, her teaching has been in evolutionary state going-from one approach to another. Another participant said that he likes the idea of post-method in L2 teaching in general and finds it a very useful approach towards the progress in this field. But he disagrees on some points with Kumaravadivelu's idea of post-method by saying though Kumaravadivelu makes his point successfully, but he is unjustifiably opponent of the concept of method by rejecting it out rightly. He does not agree with him on this point because, as he believes, methods are developed from the theories of learning, and have always been contributing a lot to L2 learning, therefore, they must not be rejected. In general, they like the idea of post-method by remarking post-method macro strategic framework is a very laudable effort towards post-method pedagogies in L2 teaching. But they do not think 'theorizing from the practice and practicing from what has theorized' is an easy task for the teachers to work independently for developing alternatives to methods in their context.

\subsection{The Evaluation of Kumaravadivelu's Post-method Macro Strategic Framework}

Majority of the participants praised the macro strategic post-method framework of Kumaravadivelu as very useful way to teach language in EFL classes. They, further, say that these macro strategies are very easy to understand and easy to practice. In this regard, one of the participants said that practicing macro strategic framework of Kumaravadivelu is easy and can be done without any special training. In contrast to this, one of the participant remarked that teachers need to be sufficiently well-versed to know the learning situations that students bring with them and besides, a teacher needs to bring some relevant material as per need to actualize 
post-method framework in his ELT classes. One of the participants, in response to a question if he would apply this macro strategic framework of Kumaravadivelu in his practice, remarks 'pick the flowers, away the thorns' and will suggest many other colleagues of his to apply Kumaravadivelu's framework in their practice as language teachers'. It is also interesting to note the comments of one participant. According to him, post-method framework contains almost all positive aspects of previous methods and has flexibility of being accommodative to any specific context. It is informative and helpful for the language practitioners to develop techniques of teaching English in the light of their contextual realities. While criticizing the framework, one participant remarked that all the teachers in his context are not able to practice this framework especially those who teach at lower and higher secondary levels. According to him, Kumaravadivelu's framework is difficult to practice in view of problems such as large classes, variation in proficiency levels of students and ability of teachers to understand and apply macro strategic framework. On the whole, they appreciated Kumaravadivelu's effort towards the post-method pedagogies by offering his post-method macro strategic framework. They agreed that it is an excellent framework in terms of both developing professional competence among teachers and improving ELT conditions in any context including their own. It is context-based and a broader approach that guides teachers on one hand, and on the other hand, it allows a necessary freedom to work within some unpredictable numerous contextual variations. However, they think that applying this framework needs teachers to have some background knowledge in L2 education.

\section{Discussion and Recommendations}

The purpose of the research was to know the views of the language practitioners about the use of post-method and method-based pedagogies in their context. The research question aimed at finding answer to the long-debated issue of the use of methods in ELT and an emerging concept of the post-method pedagogies. Although many scholars have contributed in this debate in different ways (see for instance, Allwright, 1992; Freeman, 1991; Pennycook, 1989; Prabhu, 1990; Richards, 1989; Widdowson, 1990). Research findings have shown more or less the same concerns that have already been identified in the literature review. Regarding the use of the imported methods, although the participants did not disregard the importance of methods in ELT, they talked frequently on the limitations of methods and have shown almost the same concerns that have already been recorded by some researchers (Nunan, 1987; Kumaravadivelu, 1993a) that methods are not realized in their pure forms. The findings also support the concerns of other researchers (Prahbu, 1987; Chick, 1996; Shamim, 1996; Yu, 2001; Sato, 2002) that it is difficult to practice a pedagogy successfully until it considers the contextual variations such as socio-economic, religious and cultural issues.

Although the participants do realize the limitations of the method, they accept the importance of the methods in ELT and regard them as useful theories of learning that have contributed to the language learning at different times and can be very useful at present as well if teachers use them cautiously in view of their contextual variations, and adjusting them to their learning environments. Consequently, all of the participants use different methods in their practice as language practitioners either by adjusting them to their context, or using more than one methods, or suggesting to apply eclecticism (selecting various aspects of different methods). As regard to the emergence of the post-method pedagogies, the participants welcome such idea in ELT. All of them praise such ideas as good advancement keeping in view some of the limitation in the use of the specific methods. They think that the post-method pedagogies will compensate for the limitations of the specific methods and would be adjustable to the non-native learning environment and accommodative to the socio-political environment of the context. While praising the idea of the post-method, they never withdraw from the importance of the methods in ELT.

The results of the current research correspond with the findings of the study carried about the effectiveness of Kumaravadivelu post-method framework in the EFL context of Bangladesh by Huda (2013). The findings suggest that the concept of the post-method pedagogy is both useful and applicable. However, Huda (2013) raises concerns against some aspects of this framework particularly about the macro strategy asking teachers 'to theorize from their practice and practice what they theorize'. According to him (ibid), it is difficult to practice due to number of contextual, academic and personal limitations that teachers in Bangladesh face. In contrast to Huda's analysis of this component of post method framework, one participant-teacher remarked that he has been doing the practice of theorizing one's own practice and practicing the theory on daily basis in an informal way. However, he suggests that if teachers maintain diary and manage to have discussions on regular basis, they can get more positive results from this practice. However, the remarks of another participant about the practice of theorising from one's own practice were interesting saying that she has been doing it unconsciously and comparing this practice with the practice of meditation on her own teaching. In agreement with the findings of Huda (2013), one of the participant-teachers said that teachers need to be sufficiently well-versed to know the 
learning situations that students bring with them and besides, a teacher needs to bring some relevant material as per need to actualize post-method framework in his ELT classes. The findings of the current study do not correspond with Akbari (2008) that the post-method framework does not take into account the social factors because the participants in this study believed differently saying that post method framework of Kumaravadivelu is context-based with socio-cultural touches. However, the majority of teacher-participants agreed with him (ibid), that teachers face a number of professional constraints which are not well addressed by Kumaravadivelu in his framework. The findings of the current study largely conform to Motlhaka (2015) that post-method frameworks facilitate teachers realize the limitations of method-based pedagogies and assist them to recognize their potential for developing context sensitive strategies useful for their professional development.

The study has arrived at some very interesting findings on the basis of these findings, one can suggest following recommendations regarding the context in which the actual research was carried out:

\subsection{Methods may be considered as Theories of Learning}

The debate on the search for the best method in L2 teaching has always swung between the two extremes; one group out rightly rejecting the role of methods as useless and out-dated anti-teachers, while the other group emphasizing the need of searching for some better methods. Such kind of debate hindered, rather facilitated the progress in L2 teaching. In such heightened environment of L2 teaching, a moderate stand can turn to be very useful; the participants in this research indicated such type of stand as well where they suggest benefiting from these methods as theories of learning rather as strict procedures to be applied by a language practitioner in a class.

\subsection{The Effort for Developing New Methods is Progressive towards 12 Teaching.}

No body disagrees to the fact that the development of the methods has contributed a lot in L2 teaching. The advent of every new method brings one more approach towards the language learning and becomes an additional option for language practitioners. Language teachers can utilize these methods by adjusting them to their specific contexts. As indicated in this research, all of the participants benefit from the emergence of these methods by adjusting them successfully in their learning environments.

\subsection{Post-method Pedagogy is a Favourable Option}

No doubt, the search for the post-method pedagogy is a very positive and productive approach towards L2 teaching but it may not undermine the role of methods in L2 teaching. The study participants welcomed the emergence of the post-method concept in L2 teaching and praised it as being flexible and easily fit into all learning contexts.

\subsection{Further Research}

There are so many instances where classroom research has been conducted to evaluate the importance of a method (especially in the context of CLT) in teaching of English as a second or a foreign language (see for instance Kumaravadivelu, 1993a, Nunan, 1987, Thornbury, 1996, Prahbu, 1987; Chick, 1996; Shamim, 1996; Yu, 2001; Sato, 2002). There is also a need to conduct research on the use of the post-method frameworks as suggested by Stern's three-dimensional framework (1992), Allwrigth's exploratory framework (1991) and Kumaravadivelu's post-method framework (1994). Despite the difficulty of controlling so many factors that influence the learning outcome, a comparative study can also be conducted to evaluate the significance of the post-method and the method-based pedagogies in ELT in any context. Such studies can discover more directions towards the progress of ELT profession.

\section{References}

Akbari, R. (2008). Post-method Discourse and Practice. TESOL QUARTERLY, 42(4), 641-652. https://doi.org/10.1002/j.1545-7249.2008.tb00152.x

Allwright, R. L. (1991). The death of the method (working paper \#10). The exploratory Practice, The University of Lancaster, England.

Antony, E. M. (1963). Approach, method, technique. English Language Teaching, 17, 63-67. https://doi.org/10.1093/elt/XVII.2.63

Braun, V., \& Clarke, V. (2006). Using thematic analysis in psychology. Qualitative Research in Psychology, 3(2), 77-101. https://doi.org/10.1191/1478088706qp063oa

Clarke, M. A. (1983). The scope of approach, the importance of method, and the nature of technique. In J. E. Alatis, H. Stern, \& P. Strevens (Eds.). Georgetown University Round Table on Language and Linguistics 
1983: Applied linguistics and the Preparation of Second Language Teachers (pp. 106-15). Washington, D.C.: Georgetown University.

Chick, K. J. (1996). Safe-talk: Collusion in apartheid education. In H. Coleman (Ed.). Society and language classroom (pp.21-39). Cambridge. England: Cambridge University Press.

Freeman, D. (1991). Mistaken constructs: Re-examining the nature and assumptions of language teacher education. In J. E. Alatis (Ed.), Georgetown University Round Table on Languages and Linguistics I991 (pp. 25-39). Washington, DC: Georgetown University Press.

Freeman, D. (2002). The hidden side of the work; teacher knowledge and learning to teach.A perspective from North American educational research on teacher education in English language teaching. Language Teaching, 35, 1-13. https://doi.org/10.1017/S0261444801001720

Goetz, J. P., \& LeCompte, M. D. (1984). Ethnography and Qualitative Educational Research. New York: Academic Press.

Gregg, K. (1986). Review of the input hypothesis: Issues and implications. TESOL Quarterly, 20(1), $116-122$. https://doi.org/10.2307/3586393

Huda, M. E. (2013). Post-Method Pedagogy and ELT in Bangladesh. Global Journal of Human Social Science, $X I I I(\mathrm{VII})$.

Jarvis, G. A. (1991). Research on teaching methodology: Its evolution and prospects. In B. Freed (Ed.). Foreign language Acquisition Research and the Classroom (pp. 295-306). Lexington, Massachusetts: D.C. Heath and Company.

Johnson, K. E. (2006). The Sociocultural Turn and Its Challenges for Second Language Teacher Education, TESOl Quarterly, 40(1), 235-257. https://doi.org/10.2307/40264518

Kumaravadivelu, B. (1993a). Maximizing learning potential in the communicative classroom. ELT Journal, 47(1), 12-21. https://doi.org/10.1093/elt/47.1.12

Kumaravadivelu, B. (1994b). The post-method condition: (E)merging strategies for foreign language teaching. TESOL Quarterly, 28, 27-48. https://doi.org/10.2307/3587197

Kumaravadivelu, B. (2001). Towards a post-method pedagogy. TESOL Quarterly, 35, 537-560. https://doi.org/10.2307/3588427

Kumaravadivelu, B. (2003a). Beyond methods: Macrostrategies for language teaching. New haven, CT: Yale University Press.

Kumaravadivelu, B. (2006). Understanding language teaching: from method to post-method. Mahwah, NJ. Lawrence Erlbaum.

Motlhaka. H (2015). Exploring Post-method Pedagogy in Teaching English as Second Language in South African Higher Education. Mediterranean Journal of Social Sciences, 6(1), 517-524.

Nunan, D. (1987). Communicative language teaching: Making it work. ELT Journal, 41, $136-145$. https://doi.org/10.1093/elt/41.2.136

Pennycook, A. (1989). The concept of method, interested knowledge, and the politics of language. TESOL quarterly, 23, 589-618. https://doi.org/10.2307/3587534

Prahbu, N. S. (1987). Second language pedagogy. Oxford England: Oxford University Press.

Prahbu, N.S. (1990). There is no best method-why? TESOL Quarterly, 24, 161-176. https://doi.org/10.2307/3586897

Richards, J. C. (1989). Beyond methods: Alternative approaches to instructional design. Prospect, 3(1), 11-30.

Richards, J. C., \& Rodgers, T. (1986). Approaches and methods in language teaching. Cambridge, England: Cambridge University Press.

Sato, K. (2002). Practical understanding of communicative language teaching and reacher development. In S. J. Sauvognon (Ed.). Interpreting communicative language teaching (pp.41-81). New Haven, CT.: Yale University Press.

Shamim, F. (1996). Learner resistance to innovation in classroom methodology. In H. Coleman (Ed.), Society and the language classroom (pp. 105-121). Cambridge: Cambridge University Press.

Stern, H. H. (1983). Fundamental concepts of language teaching. Oxford: Oxford University Press. 
Stern, H.H. (1992). Issues and options in language teaching. Oxford: Oxford University Press.

Tyson, E. (2011). Hip-hop healing: rap music in grief therapy with an African American adolescent male. Therapeutic uses of rap and Hip Hop, 293-305.

Walberg, H. (1977). Decision and perception: New constructs for research on teaching effects. Cambridge Journal of Education, 7, 12-20. https://doi.org/10.1080/0305764770070105

Widdowson, H.G. (1990). Aspects of Language Teaching. Oxford: Oxford University Press.

Yu, Li. (2001). Communicative language teaching in China: Progress and resistance. TESOL Quarterly, 35, 194-198. https://doi.org/10.2307/3587868

\section{Copyrights}

Copyright for this article is retained by the author(s), with first publication rights granted to the journal.

This is an open-access article distributed under the terms and conditions of the Creative Commons Attribution license (http://creativecommons.org/licenses/by/4.0/). 